\title{
OBITUARIES
}

\section{Abdulgader Mzeine}

It is with immense sadness that I record in this journal the news that Abdulgader Mzeine, former Controller of Antiquities at Cyrene, and great friend and supporter to so many working in Cyrene and the Green Mountain region of Cyrenaica, has died in Tripoli after a short illness.

Abdulgader Mzeine was born at Ras Al-Teen, Derna in 1950. A student of archaeology at the University of Benghazi (a new university, re-named Garyounis, was under construction at that time), he displayed even in those early years the gifts that he would carry through life; a commitment to the study of Classical archaeology, a natural ability to absorb and interpret information and a vibrant, sociable and popular personality.

He was appointed Inspector in the Department of Antiquities of Cyrene shortly after his graduation in May 1974. This was an inspired appointment and from the first with his self-taught fluency in Italian and English, and his deep-rooted love of Cyrene (a friend described Cyrene as 'his beating heart') he was of immense support to the Italian, American and British missions working in and around Cyrene, in Cyrenaica and further afield (he learned to excavate with Donald White in Cyrene and Charles Daniels in the Fazzan). He was from the beginning a very popular member of Department staff, much teased by his colleagues and friends in the early years of his appointment for marrying the most beautiful woman in Cyrene, for love.

As Inspector, Abdulgader took part in numerous surveys in and around Cyrene and elsewhere, including excavations on the Islamic town of Zweila in 1978, and a UNESCO survey of the wadis of the

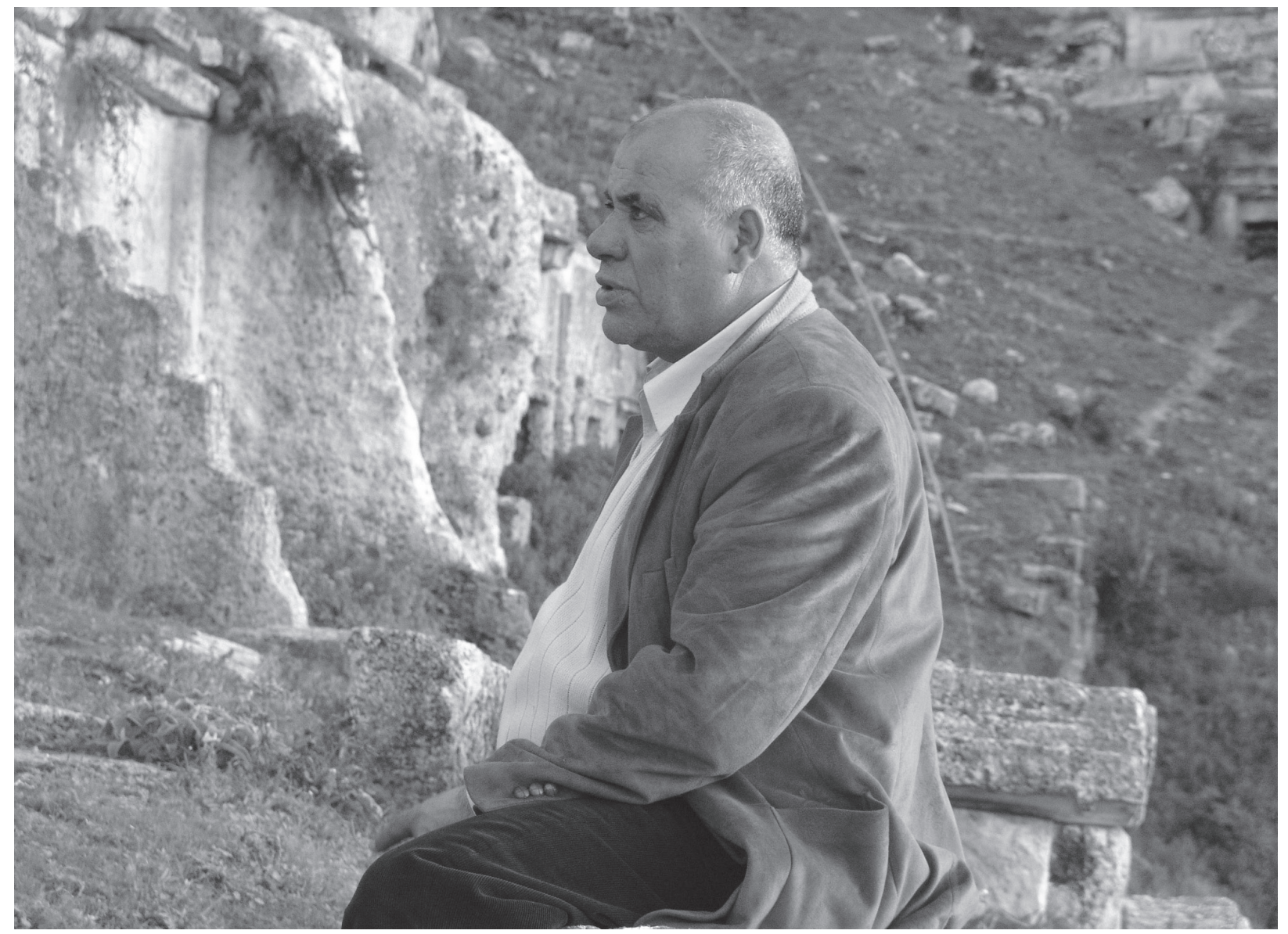

Abdulgader Mzeine during the King's College survey of Inscriptions of Roman Cyrenaica, Cyrene necropolis, 2009 (photo: H. Walda). 
Sirte area in 1995. Closer to home, he participated in a trail-blazing study with other Libyan archaeologists of archaeological sites in the Wadi Kuf, and over the years he materially contributed to our knowledge of the Green Mountain; his knowledge of the area became second to none.

In 1979 Abdulgader was awarded a training scholarship to the UK and spent six months studying the maintenance of archaeological sites and museum collections. It was after this, in the late 1980s that he struck up a particular friendship with Joyce Reynolds and Susan Walker. He had great regard for Joyce and placed enormous weight on their friendship. His friendship with Jim and Dorothy Thorn during their long-term study of the necropolis of Cyrene was particularly strong (Jim and Abdulgader first worked together with Donald White in the Sanctuary of Demeter in 1981) and no-one was prouder of their achievement in publishing the product of their labours in 2005. He was a sentimental, emotional man and I well remember the tears shed by us all when a terminally ill Jim presented a completed volume to him and to the Department in 2007. He helped Dorothy fulfil Jim's wishes to have part of his ashes scattered in the Necropolis of Cyrene in 2009.

In 1993 Abdulgader was appointed Manager of Technical Affairs and in 1998, Controller of the Department of Antiquities, Cyrene. As Inspector, Manager of Technical Affairs and Controller, he participated in many conferences on Libyan archaeology within Libya and abroad, most recently to celebrate the launch of the on-line publication of the Inscriptions of Tripolitania and Cyrenaica by Joyce Reynolds in 2009 .

A singular man with a great sense of humour, a big heart, and by then an encyclopaedic knowledge of Cyrene, its monuments, sculpture and inscriptions, as Controller (a position he was immensely proud of) he had a surprisingly effective 'laid back' style of management, reinforced by huge personality, considerable charm and great kindness. He was particularly kind and helpful to those of us working in Benghazi from 1998 onwards. He visited us and provided us with accommodation when we visited Cyrene each year. We were not an exception; he befriended and helped all the missions working in Cyrenaica.

As Libya's doors opened to tourism in the late 1990s he became a greatly sought after archaeological guide to Cyrene and other Cyrenaican sites. Despite a complete lack of interest from central and regional government and no funding, he worked tirelessly with a team from Chieti University and his own staff to establish a sculpture and inscriptions museum in a former military warehouse at Cyrene. Working alongside Emanuela Fabricotti, Oliva Menozzi and others he established, between 1998 and 2000, arguably his greatest achievement and legacy, the Cyrene Sculpture Museum. He was so very proud of this development, which has survived him as one of the great treasures of his beloved city and as an essential port of call for all visitors and tourists.

As Controller he was always keen to see archaeological missions working collaboratively at Cyrene and elsewhere and as a consequence of his encouragement multi-national teams are now active on a number of sites. He also worked tirelessly in the local community, not only as the stalwart protector of Libyan heritage in preventing damaging development from taking place (very much against the flow of national trends), but in encouraging local people to take pride in and to care for antiquities. When the American Mission returned to Cyrene in 2004, they were greeted like old friends by Abdulgader. He was well aware that the Department of Antiquities (locally and nationally) was deficient in many ways, not least in equipment and training and at his request, Susan Kane, Head of the American Mission and her husband Sam Carrier, commenced training Department staff in the use of computers, databases and GPS. Other staff members were encouraged to work alongside the missions in often distant locations to obtain experience in excavation and surveying and to develop their language skills.

Abdulgader took part in an important delegation to the UK in 2002 to discuss the repatriation of finds recovered from the Haua Fteah cave. The discussions culminated with an agreement to return the materials to Libya when a suitable facility had been built to display and keep the collection safe. At the same time, with his encouragement and the support of the then Chairman of the Department of Antiquities Giuma Anag, a new project led by Professor Graeme Barker to re-examine the cave and the pre-history of the Green Mountain was also agreed; the most recent results of that work appear in this journal. Abdulgader arranged for a rest-house to be set up for the multi-national mission near the Temple of Zeus and the early and continuing success of the project has been in consequence of his support.

In 2007 the Libyan Government announced the setting up of the World's first regional-scale conservation and development area with Cyrene at its centre. The Cyrene Declaration was announced in the Agora of Cyrene, with celebratory events taking place in various locations, including the Temple of Zeus where tented accommodation for guests was provided. The 


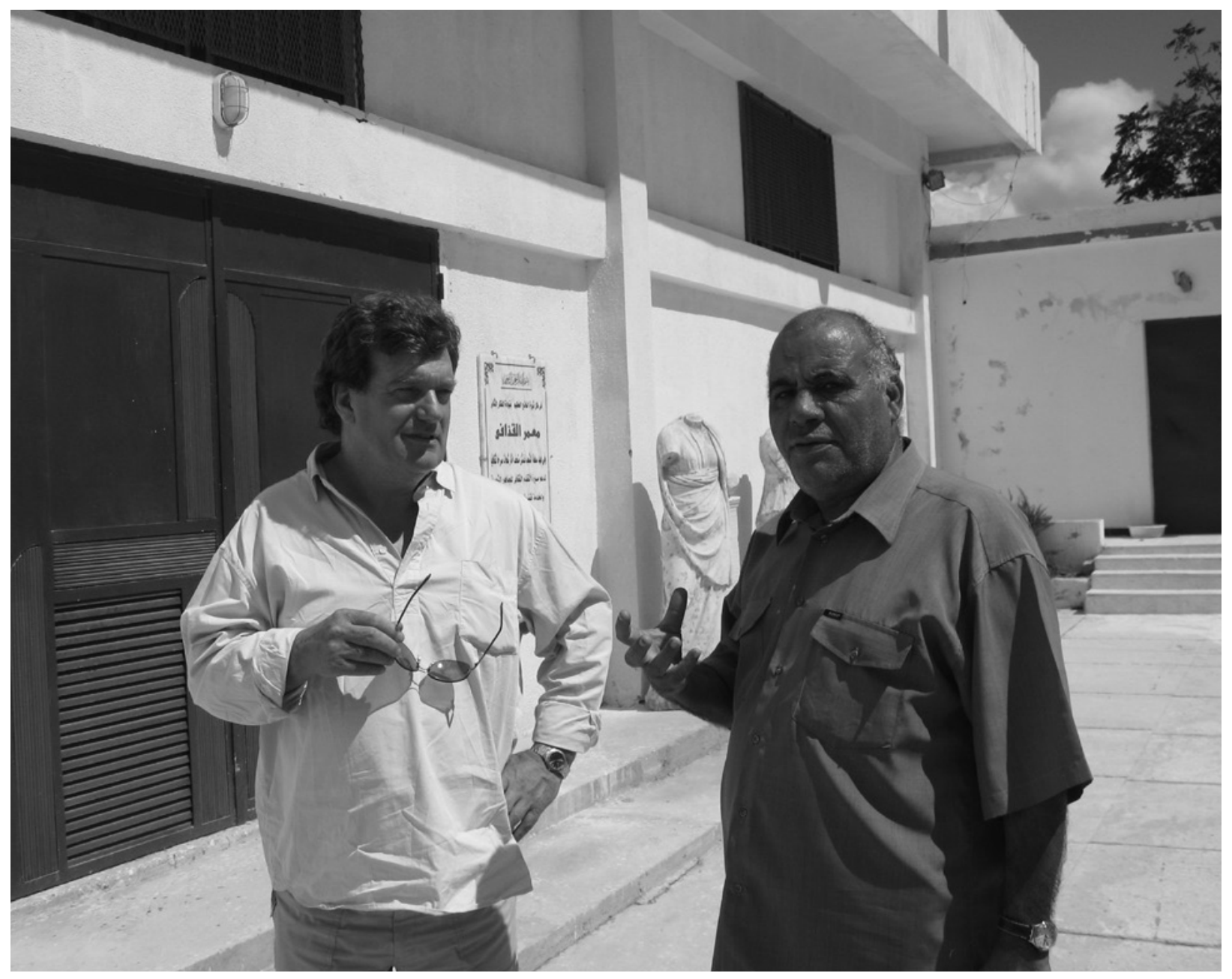

Abdulgader, outside the Cyrene Sculpture Museum with Paul Bennett in 2008 (photo: G. Barker).

event, in the spotlight of the world's media, was preceded by an unprecedented injection of cash and resources to beautify the site. With a huge workforce supported by external funding, Abdulgader organised the clearance of vegetation from vast swathes of the site, transforming the place. I had never seen him so happy, nor so active; he was in seventh heaven.

Following on from the Declaration, various reports were prepared to create protective 'buffer' zones around Cyrene and other sites in the Declaration area and to set out protocols to maintain the sites through the planning process, with much of the procedural element based on an improved and strengthened Department. Abdulgader was of enormous help with this work, particularly in identifying key problems and in communicating with and winning over the local population. This was especially the case during a study of the modern town of Shahat (built over the south-west necropolis of the ancient city), and in compiling a report to prevent a new coast road from being built across the site of Ptolemais.

When instructions were given by central government to demolish the Department of Antiquities offices at Sidi Khrebish in Benghazi with no notice in 2008 (a building where an immense quantity of material was stored, including the combined collections recovered from Euesperides and Berenice), it was Abdulgader, with Ahmed Buzaian and Yousef bin Nasser who organized lorries and manpower to move the material to places of safety.

In December 2008 Abdulgader was appointed Technical Advisor with special responsibilities for foreign missions, and it was also at this time that he was diagnosed with diabetes. The new appointment did not make up for the loss of the Controllership, but he continued to provide invaluable support for the missions, to act as an inspiring tourist guide, and to play his part in working to improve the Department of Antiquities, though he was never quite his same bouncy self.

Those archaeologists fortunate to spend survey time with him were introduced to the stunning archaeology of Cyrene and the Green Mountain, to impromptu feasts around an open fire, to good fellowship and the very best of company. Inveterate heavy smoker with an immense appetite for good 
Libyan meat and the stimulating company of friends (he was referred to as Mzeine by family and friends his sons treated him as a best friend), he was a very special man.

Susan Walker recounts a tale about Abdulgader, much retold at Cyrene, which indeed acquired the status of Cyrenaican myth: 'The Trousers of Saleh Wanis'. Once upon a time Abdulgader and his great friend and fellow Inspector Ramadan Kwaider were out surveying in the wadis west of Cyrene. After the team had finished their work and had their tea, some colleagues enjoyed a nap under a tree. Very quietly Abdulgader removed the trousers of the generously proportioned slumbering librarian Saleh Wanis. He and Ramadan occupied one leg each and thus attired hopped around the wadi to great and general amusement.

Abdulgader Mzeine, a friend of all those with a love of Libya and her archaeological heritage, died at al-Khadrah Hospital in Tripoli on 9 December 2010. He is survived by his wife, eight boys, three girls and the (other) love of his life, Cyrene.

Paul Bennett 